\title{
Contributory Pension Fund Administrations in Nigeria: Stochastic Frontier Analysis of Its Efficiency and Implications for Policy Designs
}

\author{
Babatunde Moses Ololade1, Abiodun Adewale Adegboye ${ }^{2 *}$, Rafiu Oyesola Salawu ${ }^{3}$ \\ ${ }^{1}$ Department of Accounting and Finance, Elizade University, Ilara-Mokin, Nigeria \\ ${ }^{2}$ Department of Economics, Obafemi Awolowo University, Ile-Ife, Nigeria \\ ${ }^{3}$ Department of Management and Accounting, Obafemi Awolowo University, Ile-Ife, Nigeria \\ Email: loladebabs@gmail.com, *aadegboye@oauife.edu.ng, osalawu02@yahoo.co.uk
}

How to cite this paper: Ololade, B. M., Adegboye, A. A., \& Salawu, R. O. (2019). Contributory Pension Fund Administrations in Nigeria: Stochastic Frontier Analysis of Its Efficiency and Implications for Policy Designs. Journal of Financial Risk Management, 8, 333-348. https://doi.org/10.4236/jfrm.2019.84023

Received: November 14, 2019

Accepted: December 28, 2019

Published: December 31, 2019

Copyright $\odot 2019$ by author(s) and Scientific Research Publishing Inc. This work is licensed under the Creative Commons Attribution International License (CC BY 4.0).

http://creativecommons.org/licenses/by/4.0/

\section{(c) (i) Open Access}

\begin{abstract}
The study assessed the technical efficiency of pension fund administrators in Nigeria using Stochastic Cost Frontier Model to generate efficiency scores for each of the eleven (11) selected pension fund administrators from a population of twenty-one (21). Panel data gathered from the annual reports of the selected pension fund administrators and the National Pension Commission were analysed using the maximum likelihood technique. The result showed that inefficiency, in varying degrees, existed in the selected fund administrators due to input costs on labour, equipment and premises and the mean and median efficiency scores were about $75 \%$ and $72 \%$ respectively. While the most efficient pension fund administrator recorded inefficiency score of 0.077 , the least efficient pension fund administrator had inefficiency score of 0.388 . The study concluded that increase in profitability, number of contributors, engaging in open fund investment activities and merger and acquisition reduce operating cost. It was therefore recommended that there should be a regulator-initiated merger and acquisition in the industry to eliminate waste, with positive impact on investment income. Besides, the regulatory agency should ease and expand transfer windows for existing contributors to transfer their pension contributions from an inefficient pension manager to efficient one to engender competition in the pension industry.
\end{abstract}

\section{Keywords}

Pension Fund, Frontier Analysis, Efficiency, Nigeria, Pension Reform

\section{Introduction}

The Nigerian Pension Reform Act (PRA, 2014), as amended, has significantly 
changed pension benefits from Defined Benefits (DB) to Defined Contributions (DC), which made it mandatory for all public and private employers with more than three employees to make monthly pension contributions for all their employees. Employers are to make 10\% contribution of their employees' monthly emoluments (basic salary, transport and housing allowance) while the employees are required to make $8 \%$ contribution of their monthly emolument. The total sum is to be remitted to the Pension Fund Custodian (PFC) of the employees' chosen Pension Fund Administrator (PFA).

Pension reform in Nigeria has been necessitated by the huge pension deficits amounting to $\$ 2$ trillion which cannot be met by the Federal Government out of budgetary allocations, and it has led to social and economic woes of the retirees. Besides, there are many problems associated with defined benefits (DB) pension scheme in Nigeria which are identified by Abade (2004), Orifowomo (2006), and Odia \& Okoye (2012) as the inefficiencies of the institutions saddled with the responsibilities of managing pension funds, retirees not receiving monthly pension as at when due and having to go through rigorous verification processes before the receipt of their gratuities, pensions and other retirement benefits, and corruption of pension institutions officials that misappropriated the pension fund provided by government to offset pension liabilities.

The current study is motivated by several reasons. First, private entities that are not quoted on the Nigerian Stock Exchange have licences from the National Pension Commission to manage pension contributions of employees in Nigeria, implying that there would be information asymmetry between the contributors and pension managers managing the pension fund on behalf of the contributors. Second, large proportion of the firms operating in the pension industry have parent holdings in the banking industry or some related ones. The banking industry in Nigeria, however, has consistently experienced varying degrees of operational health, with many banks that have gone under. The assessment of performance of pension fund managers would therefore be required in order to avoid some recent ugly experiences in the Nigerian banking industry.

Besides, the switch recently by Nigeria to Contributory Pension Schemes implies that post-employment benefits of all Nigerian employees in both the private and public sector will now depend on the contributions made by these employees during their active service years and investment income earned on the contributions by the pension managers. The efficiency of these pension managers in managing the pension fund assets and generating good investment income is germane to the value of monthly pension receivable and the length of periods to receive the monthly pensions at retirement as a pension manager with better investment income will render increased value of monthly pension over an extended period of time than the one that is operating with lower investment income. While the Pension Reform Act 2014 required contributors to choose their pension managers without any financial guide, the analysis of the technical efficiency of the pension fund administrators saddled with the responsibilities of 
managing pension fund contributions in Nigeria, which ought to be financial guide, has not been extensively examined in literature. Hence, a unique contribution of this study is the assessment of the technical efficiency of pension fund administrators with a view to providing financial guide to potential pension contributors in a quest to choose their pension fund administrators.

Moreover, the assessment of the performance of these private firms, based on the market values of their stocks, could be difficult or impossible except through frontier models to benchmark them. Economic efficiency is the ability of a firm to produce a given output level given a combination of optimal inputs (Coelli, 1996). Economic efficiency could either be technical efficiency or allocative efficiency. Technical efficiency is the firm's ability to produce optimum output from a given input set, while allocative efficiency is the firm's ability to use inputs of factors of production at optimal quantities while taking into consideration the available technology. Therefore, Pension Fund Administrator that is technically efficient will contribute positively to the investment income which will add to the total contributions available to the retirees at the time of drawing post-employment benefits.

Several approaches have been used in literature by researchers to assess the technical efficiency of pension fund administrators. While some authors (Garcia, 2004, 2010; Barrientos \& Boussofiane, 2005; Barros, Ferro, \& Romero, 2008) used parametric approaches, others (Ahmat, Aykut, \& Huseyin, 2013; Dalkılıç \& Ada, 2014) have used non-parametric approach. Parametric approaches are based on econometric regression models. Stochastic production, cost or profit frontier is usually estimated to generate efficiencies parameters with reference to their frontiers. Parametric techniques require econometric model which incorporates random disturbances to capture other explanatory variables not expressed in the model. The usual tests of significance can be performed in these models. On the other hand, non-parametric approaches do not require estimation of econometric parameters and they do not allow for random factors. Also, all deviations from the frontier are taken as inefficiencies. Tests of significance are not necessary in non-parametric approach and deviation from the frontier is expected to be lower than those in parametric techniques. However, the inefficiency effects are expected to be moderate.

The non-parametric tool often employed in efficiency and productivity measurement studies is Data Envelopment Analysis (DEA) while that of parametric tool is Stochastic Frontier Analysis (SFA). This study used Cobb-Douglas Stochastic Cost Frontier Analysis to assess the technical efficiencies of PFAs in Nigeria. This is because the relationship between output and input factors of production can be expressed in a functional form, and their parameters can be estimated based on the available data from the National Pension Commission (PENCOM) and financial statements of the PFAs.

\section{An Overview of Pension Fund Administration in Nigeria}

Under the new contributory pension scheme, potential contributors are meant 
to choose pension fund administrators that will manage their pension fund contributions. Employers are required to deduct and remit monthly pension contributions to the Pension Fund Custodians (PFCs) of the contributors' chosen Pension Fund Administrators (PFAs). While the custodians hold the pension fund for safe keeping purposes, the administrators administer and invest the pension fund into different asset classes based on the investment guidelines issued by National Pension Commission (PENCOM), the regulatory authority of the pension industry. As at December 2017, there are twenty-one (21) licenced pension fund administrators, seven (7) closed pension fund administrators and four (4) pension fund custodians.

The total pension fund assets as at $31^{\text {st }}$ December 2015 is N5.3 trillion and has grown to N7.5 trillion ( $\$ 24.6 \mathrm{~b}$, at official rate of 305 to $\$ 1$ ) as at $31^{\text {st }}$ December, 2017 (PENCOM, 2018). This implies a growth rate of $29 \%$ more than the growth rate of the Nigerian Gross Domestic Products (GDP) which is 3.1\%. The pension fund assets had become critical financial assets for economic development and the assessment of its efficient management is expected to be continuous with a view to meeting the objectives of setting up the fund. An analysis of the investment of the pension fund in the financial markets showed that greater percentage of the fund were invested in Federal Government of Nigeria Securities (70.43\%), followed by local money market securities $(9.07 \%)$ and domestic ordinary shares (8.94\%). Table 1 shows the industry portfolio summary of pension

Table 1. Asset composition of pension funds' assets in Nigeria.

\begin{tabular}{|c|c|c|c|c|c|c|}
\hline ASSET CLASSES & AES & CPFAs & $\begin{array}{l}\text { RSA ACTIVE } \\
\text { ACCOUNT }\end{array}$ & $\begin{array}{l}\text { RSA RETIREE } \\
\text { ACCOUNT }\end{array}$ & $\begin{array}{l}\text { TOTAL PENSION } \\
\text { FUND ASSETS }\end{array}$ & WEIGHT \\
\hline & \#Billion & \#Billion & \#Billion & \#Billion & \#Billion & $\%$ \\
\hline Quoted Ordinary Shares & 93.01 & 65.06 & 509.66 & 4.27 & 672.00 & 8.94 \\
\hline FGN Securities & 536.64 & 536.57 & 3799.34 & 419.83 & 5292.38 & 70.43 \\
\hline State Govt Securities & 11.92 & 15.80 & 109.22 & 15.46 & 152.40 & 2.03 \\
\hline Corporate Debt Instruments & 27.37 & 42.84 & 161.39 & 36.52 & 268.12 & 3.57 \\
\hline Money Market Instruments & 63.17 & 63.09 & 475.98 & 79.11 & 681.35 & 9.07 \\
\hline Mutual Fund & 1.87 & 8.54 & 14.58 & - & 24.99 & 0.33 \\
\hline Supra-National Bonds & - & 2.26 & 6.10 & 3.07 & 11.43 & 0.15 \\
\hline Private Equity Funds & - & 11.28 & 14.16 & - & 25.44 & 0.34 \\
\hline Infrastructure Funds & - & 1.76 & 3.96 & - & 5.72 & 0.08 \\
\hline Real Estate Properties & 93.96 & 111.37 & - & - & 205.33 & 2.73 \\
\hline Foreign Investments & - & 140.00 & - & - & 140.00 & 1.86 \\
\hline Foreign Equities & - & 104.61 & - & - & 104.61 & 1.39 \\
\hline Foreign Money Market Securities & - & 35.39 & - & - & 35.39 & 0.47 \\
\hline Cash and Other Assets & 0.21 & 10.29 & 19.82 & 4.78 & 35.10 & 0.47 \\
\hline Net Asset Value & 828.15 & 1008.86 & 5114.21 & 563.04 & 7514.26 & 100 \\
\hline
\end{tabular}

Source: Pension Commission, Nigeria (2017). Note: AES = Approved Existing Schemes; CPFA = Closed Pension Fund Administrator; FGN = Federal Government of Nigeria; Govt = Government; RSA = Retirement Savings Account. 
fund assets in Nigeria as at $31^{\text {st }}$ December 2017. It reveals the classes of assets into which pension fund administrators invest pension contributions. The assets range from variable income securities (e.g. Equity shares, Mutual and Private Equity Fund) to fixed income securities (e.g. Federal Government of Nigeria bonds, State Government bonds, Supra-National bonds, Corporate bonds etc.). Evidence from Table 1 also shows that $9.61 \%$ of the total contributions were invested in variable income securities, $90.86 \%$ were invested in fixed income securities and $0.47 \%$ held in cash and other assets.

\section{Review of Related Literature}

\subsection{Theoretical Framework}

The study is anchored on theory of production frontier. Production frontier shows the minimum input of factors of production required to produce maximum output given the available technology. Producers operating on their production frontier are said to be technically efficient while those that are operating below their production frontier are said to be technically inefficient. Technical Efficiency (TE) measures the firm's ability to attain optimum output given the set of input parameters. Pension fund administrators are usually assessed using their stock returns as means of assessment Barros \& Garcia (2007). However, this cannot be used in Nigeria as all the pension fund administrators analysed are not quoted on the Nigeria Stock Exchange. Therefore, their stock returns are not available, and it is appropriate to adopt production frontier models to assess the performance of the unquoted pension fund administrators. Besides, pension fund administrators seem to follow the same investment strategies which make ranking based on out-performance difficult to achieve. This further gives credence to the use of stochastic frontier model in assessing the technical efficiency of pension fund administrators.

Two approaches have been widely used in literature in assessing efficiency: parametric and non-parametric approaches. While stochastic cost frontier, stochastic production frontier, and stochastic profit frontier are parametric approaches that could be used, the non-parametric approaches include the Data Envelopment Analysis (DEA) and Free Disposal Hull (FDH). The DEA model was created by Farrell (1957) and advanced by Charnes, Cooper, \& Rhodes (1978) to analyze the technical efficiency of public and non-profit making organizations. Table 2 shows the DEA models used in literature for analyzing the technical efficiency of pension fund administrators, the input and output variables used in analysis and the summary of results.

Using DEA as a data estimation technique in analyzing the technical efficiency of the pension managers in Nigeria will be confronted with challenges of data as all the pension fund administrators in Nigeria are not listed entities and as such information on the number of employees, marketing and sales costs and executive pay will be difficult to obtain. However, Stochastic Frontier Analysis is considered appropriate for this study because of the availability of data to carry out 
Table 2. Studies with data envelopment analysis (DEA).

\begin{tabular}{|c|c|c|c|c|c|}
\hline $\mathbf{S} / \mathbf{N}$ & Author/Title & Input Variables & Output Variables & Model type & Findings \\
\hline 1 & $\begin{array}{l}\text { Barrientos \& Boussofiane } \\
(2005) . \text { How efficient are } \\
\text { pension fund managers in } \\
\text { Chile? }\end{array}$ & $\begin{array}{l}\text { The input variables are: } \\
\text { office personnel costs, } \\
\text { marketing and sales } \\
\text { costs, executive pay, and } \\
\text { administration \& } \\
\text { computing costs. }\end{array}$ & $\begin{array}{l}\text { Total revenue and } \\
\text { the number of the } \\
\text { contributors. }\end{array}$ & $\begin{array}{l}\text { Charnes, Coopers } \\
\text { and Rhodes (CCR) } \\
\text { Model and Banker, } \\
\text { Charnes and Coopers } \\
\text { (BCC) Model. }\end{array}$ & $\begin{array}{l}\text { The Pension fund managers in Chile are } \\
\text { found to be technically inefficient as they } \\
\text { all operated below the estimated efficient } \\
\text { frontier. Also, there is no evidence to } \\
\text { suggest that the fund managers' } \\
\text { performance will improve overtime. }\end{array}$ \\
\hline 2 & $\begin{array}{l}\text { Ahmat, Aykut, \& } \\
\text { Huseyin (2013). } \\
\text { Improvement of private } \\
\text { pension in Turkey and } \\
\text { measurement of its } \\
\text { efficiency with data } \\
\text { envelopment analysis. }\end{array}$ & $\begin{array}{l}\text { Numbers of personnel } \\
\text { and total assets. }\end{array}$ & $\begin{array}{l}\text { Total fund and total } \\
\text { amount of } \\
\text { premiums. }\end{array}$ & CCR Model. & $\begin{array}{l}\text { The private pension companies exhibited } \\
\text { average efficiency level in the industry } \\
\text { though there had been slight changes in } \\
\text { the last } 6 \text { years. Also, large-scaled } \\
\text { company group recorded efficiency } 0 \\
\text { levels when compared to the small-scaled } \\
\text { company group. Besides, domestic private } \\
\text { pension companies recorded lower } \\
\text { efficiency levels when compared to } \\
\text { foreign private pension companies. }\end{array}$ \\
\hline 3 & $\begin{array}{l}\text { Dalkılıç \& Ada (2014). } \\
\text { Efficiencies of life and } \\
\text { pension insurance industry } \\
\text { in Turkey: An application } \\
\text { of data envelopment } \\
\text { analysis. }\end{array}$ & $\begin{array}{l}\text { Shareholders' equity, } \\
\text { operating expenses, } \\
\text { number of agencies and } \\
\text { number of staff } \\
\text { employed by insurance } \\
\text { companies. }\end{array}$ & $\begin{array}{l}\text { Net gross } \\
\text { premiums, net } \\
\text { claims and net } \\
\text { technical } \\
\text { provisions. }\end{array}$ & $\begin{array}{l}\text { Input drive BCC } \\
\text { model. }\end{array}$ & $\begin{array}{l}\text { The average scale efficiency of } 92 \% \text { in } \\
2010 \text { and } 88.7 \% \text { in } 2011 \text { was found, } \\
\text { implying a decrease of } 3.3 \% .14 \\
\text { companies were efficient in } 2010 \text {, while in } \\
12 \text { companies were found efficient in } \\
2011 \text {. }\end{array}$ \\
\hline
\end{tabular}

Source: Author's Compilation.

the analysis, the study will contribute to knowledge by considering portfolio returns as one of the variables in the analysis which previous empirical studies did not consider as one of the inputs in stochastic model to assess technical efficiency which is an important determinant of the extent of post-employment benefits to be taken at retirement. The empirical contribution of the frontier analyses would also allow an assessment of the factors which affect PFA's performance and as well as those beyond their full control. Furthermore, assessments of the technical efficiency of pension fund managers are very limited in Africa and $\mathrm{Ni}$ geria most especially despite the pension reforms in both the public and private sectors and crucial roles perform by the pension fund managers in ensuring that the only social security fund in Nigeria is managed efficiently. The study fills the gap.

\subsection{Empirical Literature}

Braberman, Chisari, Quesada, \& Rossi (1999) studied Argentinean pension fund management companies using a Cobb-Douglas cost frontier model to analyze quarterly data from 1997Q2 to 1998Q1. Operating costs as dependent variable were regressed against profitability of the fund, number of members and positive turnover as independent variables. Changes in regulation in the industry after November 1997 were represented with two dummy variables. The study concluded that though regulation did not significantly affect technical efficiency it 
increased total costs of pension fund management companies.

Barros, Ferro, \& Romero (2008) examined the technical efficiency of pension funds management companies in Argentina using a parametric econometric tool to estimate the parameters of factor prices of labour and capital including the output and subsequently used the estimated efficiency parameters to rank the performance of pension fund management companies. The study revealed that the cost parameters recorded the expected efficiency estimates and the price of capital-premises and the number of participants is heterogeneous among the Argentinean pension funds management companies. Besides, merger and acquisition are positives signifying that mergers and acquisition decreases cost and finally, the relationship between market share and costs is negative perhaps because of economies of scale related to their estimation.

Barros \& Garcia (2006) studied sample of pension fund management companies in Portugal using four DEA models and opined that the DEA models are inadequate to reveal out-performance between pension fund management companies in Portugal with most funds having almost the same performance. The study also found correlations between efficiency and private/public status, mergers/acquisition and scale. Further work by Barros \& Garcia (2007) analysed the sample using parametric econometric tool and found that operating cost increased as the price of labour and capital-management services increased while total cost decreased with profit and increase in the number of contributors and open fund. The study also found that total cost decreased with open fund and merger and acquisition activities.

Table 3 shows the Stochastic cost frontier models used in literature for analysing the technical efficiency of pension fund managers, the input and output variables used in analysis and the summary of results.

\section{Data and Methodology}

The study focused on the existing twenty-one (21) PFAs licensed by PENCOM to manage the pension contributions in Nigeria. The selected PFAs constitute the sample of the study using purposive sampling technique. The eleven PFAs were taken based on their pension fund asset size, and complete set of financial statements from 2011-2015. Secondary data were sourced from the published financial statements of the sampled PFAs and annual reports of National Pension Commission.

Panel data on operating cost, price of labour (that is staff cost divided by the book value of total asset), price of capital-management services (commission and fees divided by fund under management), price of capital-premises (expenditure on equipment and premises dividend by the book value of total assets), profit (profit after tax), portfolio returns (annual rate of return multiply by fund under management) were obtained from the published annual reports of the selected PFAs. Moreover, data on number of the contributors for each of the PFAs were obtained from PENCOM. Dummy variables were equally used to 
Table 3. Studies with stochastic cost frontier analysis of pension fund efficiency.

\begin{tabular}{|c|c|c|c|c|c|}
\hline $\mathrm{S} / \mathrm{N}$ & Article & Input Variables & Output Variables & $\begin{array}{l}\text { Cobb-Douglas } \\
\text { Model }\end{array}$ & Summary results. \\
\hline 1 & $\begin{array}{l}\text { Barros \& Grarcia (2007). } \\
\text { Analysing the performance of } \\
\text { pension fund industry with a } \\
\text { stochastic frontier model: A } \\
\text { case study of Portugal. }\end{array}$ & $\begin{array}{l}\text { Prices of labour, } \\
\text { management services, and } \\
\text { capital-premises }\end{array}$ & $\begin{array}{l}\text { Profits and number } \\
\text { of participants. }\end{array}$ & $\begin{array}{l}\text { Cobb-Douglas } \\
\text { stochastic cost } \\
\text { frontier model. }\end{array}$ & $\begin{array}{l}\text { The efficiency score of each } \\
\text { pension manager was derived and } \\
\text { this could be used to predict their } \\
\text { future capacity to earn fair returns } \\
\text { for the participants. }\end{array}$ \\
\hline 2 & $\begin{array}{l}\text { Keshari \& Paul (1994). Relative } \\
\text { efficiency of Foreign and do- } \\
\text { mestic banks. }\end{array}$ & $\begin{array}{l}\text { Labour, Capital and } \\
\text { material inputs Labour input } \\
\text { follows Subrahmanyam \& } \\
\text { Swani (1992). }\end{array}$ & $\begin{array}{l}\text { Sum of total amount } \\
\text { of deposits and } \\
\text { advances of a bank. }\end{array}$ & $\begin{array}{l}\text { Stochastic frontier } \\
\text { production } \\
\text { function. }\end{array}$ & $\begin{array}{l}\text { Foreign bank group was } 1 \% \text { less } \\
\text { efficient than the domestic. The } \\
\text { banks were found to record the } \\
\text { same level of efficiencies. }\end{array}$ \\
\hline 3 & $\begin{array}{l}\text { Lozano-Vivas, Kumbhakar, } \\
\text { Fethi, \& Shaban (2011). } \\
\text { Consolidation in European } \\
\text { banking industry: How } \\
\text { effective is it? }\end{array}$ & $\begin{array}{l}\text { Deposits were used as both } \\
\text { inputs and outputs at the } \\
\text { same time. The inputs are } \\
\text { borrowed funds, labour, and } \\
\text { physical capital. }\end{array}$ & $\begin{array}{l}\text { The output variables } \\
\text { include loans, } \\
\text { deposits, and other } \\
\text { earning assets. }\end{array}$ & $\begin{array}{l}\text { Stochastic Cost } \\
\text { frontier approach. }\end{array}$ & $\begin{array}{l}\text { The study found that banks that } \\
\text { were involved in cross-border } \\
\text { mergers are more cost efficient } \\
\text { when compared to banks that } \\
\text { were involved in domestic } \\
\text { mergers. }\end{array}$ \\
\hline 4 & $\begin{array}{l}\text { Karim }(2001) \text {. } \\
\text { Comparative bank efficiency } \\
\text { across selected ASEAN } \\
\text { countries. }\end{array}$ & $\begin{array}{l}\text { Expenses on wages and } \\
\text { salaries, land, buildings, \& } \\
\text { equipment and interest per } \\
\text { dollar of deposits }\end{array}$ & $\begin{array}{l}\text { Dollar amounts of } \\
\text { commercial, } \\
\text { industrial and other } \\
\text { loans; time deposits, } \\
\text { demand deposits, } \\
\text { and securities \& } \\
\text { investments. }\end{array}$ & $\begin{array}{l}\text { Stochastic cost } \\
\text { function model. }\end{array}$ & $\begin{array}{l}\text { The study found significant } \\
\text { differences in efficiency across } \\
\text { ASEAN banks with the Thai bank } \\
\text { being the least efficient. Larger } \\
\text { banks seem to be less technical } \\
\text { efficient compared to smaller } \\
\text { banks. }\end{array}$ \\
\hline 5 & $\begin{array}{l}\text { Gouhua \& Apostolos (2009). } \\
\text { Efficiency and productivity of } \\
\text { the US banking industry, } \\
\text { 1998-2005: Evidence from } \\
\text { frontier cost function satisfying } \\
\text { global regulatory conditions. }\end{array}$ & $\begin{array}{l}\text { All core deposits and } \\
\text { purchased funds and financial } \\
\text { equity capital. Also, wage rate, } \\
\text { the interest rate for borrowed } \\
\text { funds, and price of physical } \\
\text { capital. }\end{array}$ & $\begin{array}{l}\text { Consumer loan, } \\
\text { non-consumer loans } \\
\text { such as } \\
\text { industrial \& } \\
\text { commercial loans \& } \\
\text { real estate loans; and } \\
\text { securities. }\end{array}$ & $\begin{array}{l}\text { Frontier stochastic } \\
\text { cost function. }\end{array}$ & $\begin{array}{l}\text { Banks with assets greater than } \$ 1 \\
\text { billion in } 1998 \text { are less efficient } \\
\text { than the other subgroups. Also, } \\
\text { the largest four banks subgroups } \\
\text { (with assets greater than } \$ 400 \\
\text { million) experienced significant } \\
\text { productivity gains when compared } \\
\text { to the smallest eight banks } \\
\text { subgroups. }\end{array}$ \\
\hline 6 & $\begin{array}{l}\text { Greene \& Segal (2004). } \\
\text { Profitability and efficiency in } \\
\text { the U.S life insurance policy. }\end{array}$ & Labour, capital and materials. & $\begin{array}{l}\text { Amount of life } \\
\text { insurance, total } \\
\text { annuity, total } \\
\text { premiums, and } \\
\text { investment. }\end{array}$ & $\begin{array}{l}\text { Stochastic cost } \\
\text { function model. }\end{array}$ & $\begin{array}{l}\text { The study found significant cost } \\
\text { inefficiency in the life insurance } \\
\text { industry when compared to } \\
\text { earnings and that there is negative } \\
\text { relationship between inefficiency } \\
\text { and profitability. }\end{array}$ \\
\hline
\end{tabular}

Source: Author's Compilation.

denote open fund, closed fund and merger and acquisition based on the information obtained from the pension fund administrators' bulletins and PENCOM website (PENCOM Annual Reports, 2010-2015).

\section{Model Specification}

The model used for assessing the technical efficiency of the pension fund was Cobb-Douglas Stochastic Frontier Cost Model. The model was developed by Farrell (1957) and later used Aigner, Lovell, \& Schmidt (1977), Battese \& Corra (1977), and Meeusen \& Van de Broeck (1977). The model is specified as: 


$$
C_{n t}=F\left(R_{\mathrm{int}}, S_{\mathrm{int}}\right) \cdot e^{V_{n t}+U_{n t}} \quad i=1,2, \cdots, N ; t=1,2, \cdots, N
$$

$C_{n t}=$ scalar cost of $n$th pension fund management company in the $n$th period. This is the total operating cost of each of the pension management company which represents the total of input cost;

$R_{\text {int }}=$ vector of the $i$ th input prices of the $n$th pension fund management company in the $n$th period. These are price of labour, price of capital-management services and price of capital-premises for all the period of the study and;

$S_{\text {int }}=$ vector of the $i$ th output descriptors of the $n$th pension fund management company observed in the nth period. These are outputs expected of pension fund management company inform of profit, portfolio returns, number of contributors, existence of closed and opened fund and mergers and acquisitions;

$V_{n t}=$ traditional error term of econometric model. This represents random shocks and independent of $U_{n t}$;

$U_{n t}=$ inefficiency terms. It represents technical inefficiencies and is assumed to be positive and distributed normally with zero mean and variance $\sigma^{2} u$. It is showed in a half-normal independent distribution truncated at zero. It is management shock controlled by the pension fund administrators.

Generalised stochastic Cobb-Douglas cost frontier model was estimated with three input prices (one price of labour and two prices of capital), and six outputs (profits, portfolio returns, number of contributors, number of closed funds and the existence or not of open funds under management and merger and acquisition). The model as specified in Coelli, Rao, \& Battese (1998) above could be expressed econometrically as follows:

$$
\begin{aligned}
\log \left(\frac{C_{n t}}{P K 2_{n t}}\right)= & \beta_{0}+\beta_{1} \log \left(\frac{P L_{n t}}{P K 2_{n t}}\right)+\beta_{2} \log \left(\frac{P K 1_{n t}}{P K 2_{n t}}\right)+\beta_{3} \log \left(\frac{P K 2_{n t}}{P K 2_{n t}}\right) \\
& +\beta_{4} \log \left(\frac{\text { profits }_{n t}}{P K 2_{n t}}\right)+\beta_{5} \log \left(\frac{\text { portfolio returns }_{n t}}{P K 2_{n t}}\right) \\
& +\beta_{6} \log \left(\text { Contributors }_{n t}\right)+\beta_{7} \log \left(\text { Closed }_{n t}\right)+\beta_{8} \log \text { Open }_{n t} \\
& +\beta_{9} \mathrm{M} \& \mathrm{~A}+V_{n t}+U_{n t}
\end{aligned}
$$

where: $P L=$ the price of labour, measured by dividing total staff cost by the book value of total assets.

$P K 1=$ Price of capital-management services, measured by dividing commissions and fees by the value of the fund under management.

$P K 2=$ the price of capital-premises, measured by dividing the expenditure on equipment and premises by the book value of total assets.

$C=$ Total operating costs.

Profit $=$ Profit after tax of the pension fund administrators.

Portfolio returns $=$ Annual portfolio returns of the pension fund administrator, measured by multiplying the annual rate of return with the value of the fund under management.

Contributors $=$ Numbers of contributors. 
Closed Fund $=$ Dummy variable which is one if there are closed fund under management and zero otherwise.

Open Fund $=$ Dummy variable which is one if there are open fund under management and zero otherwise.

Merger \& Acquisition = Dummy variable: it is one if pension fund has been involved in mergers and acquisitions in the period and zero otherwise.

The variables are defined in literature by Barros \& Garcia (2007) and Barros, Ferro, \& Romero (2008). The traditional log-log econometric specification was used to allow for the non-linearity of the frontier. The variables were expressed over PK2 (Expenditure on premises and equipment) to impose the linear homogeneity of the input variables. Input and output variables are very crucial in assessing the technical efficiency of firms. Coelli, Rao, \& Battese (1998) model was adopted for the study because data of the input variables of price of labour and capital are available to assess the technical efficiency of the PFAs in Nigeria.

\section{Results and Discussions}

\subsection{Basic Descriptive Statistics}

All the variables are expressed in their raw data form. The results are presented in Table 4 which shows the mean, standard deviation, minimum and maximum values of each variable. Table 4 shows that the series display consistency in relation to their mean values.

As shown in Table 4, the PFAs in Nigeria have an average operating cost of $\$ 1,777,957$ billion with an estimated minimum value of $\$ 176,770$ million and maximum value of $\$ 6,645,126$ billion. The standard deviation values for the variables exhibit moderate deviation from their mean values except that of the profit. There is therefore less variation in the values of the variables for the pension fund administrators in Nigeria. On the average, portfolio return is estimated at $\$ 3,517,576$ billion with a minimum value of $\$ 191,709$ million and maximum value of $\$ 23,483,460$ billion. This implies that there is below average net portfolio return of some pension fund administrators in Nigeria when operating cost is taken into considerations in determining the net returns.

\subsection{Cobb-Douglas Cost Frontier Pension Fund Function}

The estimation of Stochastic Cost frontier model is as specified in Coelli, Rao, \& Battese (1998) using the assumption of half-normal distribution. The result is as shown in Table 5.

${ }^{1}$ Greene (2005)'s true fixed-effects and Battese \& Coelli (1988)'s time-invariant were used to estimate the data, but the results obtained were not meaningful. Table 5 highlights estimation of stochastic cost frontier. The figures in parentheses are the calculated probability values of t-statistics.

${ }^{1}$ In order to examine the sensitivity of results in this study an attempt was made using translog function of other models and their distributions to estimate the data, but no meaningful results were obtained. 
Table 4. Basic descriptive statistics.

\begin{tabular}{cccccc}
\hline Variable & Observation & Mean & Standard Deviation & Minimum & Maximum \\
\hline Operating Cost & 55 & $1,777,957$ & $1,422,332$ & $176,770.0$ & $6,645,126$ \\
Price of Workers & 55 & 0.262138 & 0.120093 & 0.128600 & 1.034100 \\
Capital-Mgt. Service & 55 & 0.017027 & 0.002638 & 0.012300 & 0.030200 \\
Capital-Premises & 55 & 0.140684 & 0.132937 & 0.020500 & 0.610300 \\
Profit & 55 & $1,241,931$ & $2,184,785$ & $-16,890.00$ & $11,577,795$ \\
Portfolio Return & 55 & $3,517,576$ & $4,488,060$ & $191,709.0$ & $23,483,460$ \\
Numbers of Contributors & 55 & $437,279.4$ & $327,140.5$ & $20,168.00$ & $1,452,481$ \\
Closed fund & 55 & 0.905660 & 0.295098 & 0 & 1 \\
Open fund & 55 & 0.943396 & 0.233295 & 0 & 1 \\
Merger and Acquisition & 55 & 0.283019 & 0.454776 & 0 & 1 \\
\hline
\end{tabular}

Source: Author's compilation.

Table 5. Estimates of cobb-douglas cost function.

\begin{tabular}{|c|c|c|}
\hline Variable & Parameter & Coefficient with p-value in parenthesis \\
\hline \multicolumn{3}{|l|}{ Opec $(\log \mathrm{OC})$} \\
\hline$P L(\log p w)$ & $\beta_{1}$ & $0.1392(0.020)^{\star \star}$ \\
\hline$P K 1$ (logmserv) & $\beta_{2}$ & $0.0401(0.722)$ \\
\hline$P K 2$ (logcap) & $\beta_{3}$ & $0.0053(0.815)$ \\
\hline Lpfit (logprofit) & $\beta_{4}$ & $-0.2037(0.001)^{* * *}$ \\
\hline Lpotr (logptret) & $\beta_{5}$ & $1.1246(0.000)^{\star * *}$ \\
\hline Lcont (logentr) & $\beta_{6}$ & $-0.0196(0.623)$ \\
\hline Closed & $\beta_{7}$ & $0.2047(0.015)^{\star *}$ \\
\hline Open & $\beta_{8}$ & $-0.0544(0.479)$ \\
\hline MA & $\beta_{9}$ & $-0.1650(0.003)^{* * *}$ \\
\hline Constant & $\beta_{0}$ & $1.0596(0.135)^{*}$ \\
\hline Sigma $^{2}$ & $\sigma^{2}=\sigma_{u}^{2}+\sigma_{v}^{2}$ & 0.3055 \\
\hline $\operatorname{Gamma}(\gamma)$ & $\gamma=\sigma_{u}^{2} / \sigma_{u}^{2}$ & 0.9835 \\
\hline Prob $>$ Chi2 & & $0.0000^{\star * *}$ \\
\hline L-R Chi2 & & 2177.29 \\
\hline Log-likelihood & L.L.F & 53.1318 \\
\hline
\end{tabular}

Source: Author's compilation. Note: ${ }^{* * *},{ }^{* *}$ and ${ }^{\star}$ denote $p<0.01, p<0.05$ and $p<0.1$ significance level respectively.

A close look at the variables reveals that price of worker (PL) which have a positive coefficient value of 0.1392 with operating cost implies that $1 \%$ increase in price of worker would increase operating cost by $14 \%$. Also, price of capital-management service $(P K 1)$ which shows positive coefficient value of 0.0401 with operating cost, indicates that $1 \%$ increase in price of capital-management 
service would increase operating cost by $4 \%$. Similarly, price of capital-premises $(P K 2)$ reveals positive coefficient of 0.0053 with operating cost. This implies that $1 \%$ increase in price of capital-premises ( $P K 2$ ) would increase operating cost of pension fund administration by $5 \%$. Profit has negative coefficient of 0.2037 with operation cost, it suggests that $1 \%$ increasein profit will lead to $20 \%$ percent decrease in operating cost. Furthermore, portfolio returns with positive coefficient value of 1.1246 with operating cost, implies that $1 \%$ increase in portfolio returns would increase operating cost by $112 \%$. The pension managers operate under a very strict investment guidelines specified by the regulatory agency, PENCOM and these have restricted the capacity of the pension managers to earn portfolio returns without increasing operating costs. The investment guidelines specified greater percentage of the pension fund assets to be invested into government gilt-edged securities. Hence, the portfolio returns depend on the market specified rate.

It is also deduced that contributors with negative coefficient of 0.0196 with operating cost, implies that $1 \%$ increase in numbers of contributors will reduce operating cost by $19.6 \%$. Consequently, closed fund with positive coefficient value of 0.2047 with operating cost, suggests that $1 \%$ increase in closed fund investment will lead to increase in operating cost by $20 \%$. In the same vein, open fund with negative coefficient of 0.0544 with operating cost, reveals that $1 \%$ increasein open fund investment will reduce operating cost by $5 \%$. Meanwhile, Merger and acquisition which indicates negative coefficient value of 0.1650 with operating cost, suggests that $1 \%$ increase in merger and acquisition of pension fund firms will lead to decrease in cost of operation by $16.5 \%$.

The overall chi-square value of 2177.29 and probability of 0.000 implies that in general the results are statistically significant. The operating costs increase as all the factors of production increase, except for number of contributors, profits, open fund and mergers and acquisition. Operating costs could be reduced significantly through acquisition of more contributors by the pension fund administrators as the number of contributors increase the size of the pension fund. In the case of profit, cost must be strategically curtailed by the pension fund administrators to sustain the business of pension fund management in perpetuity. Open fund contributes toward cost curtailment and this could be because of the flexibility embedded in open fund investment in relation to close fund. In case of merger and acquisition, this reveals that the strategy of merger and acquisition in pension fund management contributes towards efficiency. There has been mergers and acquisition in the industry which were carried out with the view to having the advantages of synergy and economic of scales. The results from the analysis of data as stated above are consistent with the findings of Barros \& Garcia (2007); Ferro, Romero, \& Covelli (2011) and Barrientos \& Boussofiance (2005).

\subsection{Pension Fund and Technical Efficiency Scores}

Table 6 presents a ranking of the efficiency scores of the PFAs as estimated from the cost function. 
Table 6. Efficiency scores of pension funds in Nigeria.

\begin{tabular}{cc}
\hline Pension Fund Administrators & Efficiency Scores \\
\hline AIICO Pensions & 0.923 \\
NLPC Pensions & 0.919 \\
Legacy Pensions & 0.823 \\
Premium Pensions & 0.816 \\
Sigma Pensions & 0.773 \\
Stanbic IBTC Pension Managers & 0.718 \\
Trustfund & 0.685 \\
FUG Pensions & 0.652 \\
Leadway Pensions & 0.652 \\
ARM & 0.620 \\
Pension Alliance Limited & 0.612 \\
Mean & $\mathbf{0 . 7 4 5}$ \\
Median & $\mathbf{0 . 7 1 8}$ \\
Standard Deviation & $\mathbf{0 . 0 7 8}$ \\
\hline
\end{tabular}

Source: Author's Compilations.

The technical efficiency refers to a situation on the frontier. It is achieved by firm that allocates minimum resources to produce maximum output and without waste of resources. Firms with a score of one are on the frontier and are thus efficient while firm below one is below the cost frontier and are thus less efficient. The value of waste in the production process of a firm is measured by taking the difference between one and the estimated efficiency score of each of the pension fund administrators. The efficiency scores in Table 6 showed that there was inefficient allocation of resources in the management of pension fund asset portfolios in Nigeria. The most efficient PFA is AIICO Pension though there is $(1-0.923=0.077)$ waste that needed to be eliminated from its production processes. The least efficient PFA, Pension Alliance Limited (PAL) has (1 $0.612=0.388$ ) waste or underutilised resources to be eliminated from its production processes to be technically efficient. All the PFAs have varying degrees of waste that needed to be removed for them to upgrade their financial performance.

The mean score is 0.745 . This means that the pension fund administrators can reduce their operating costs by $25.5 \%$, which were the price of labour, price of capital-premises and price of capital-management services without decreasing their output. The maximum efficiency is one and there is no PFA that achieves maximum efficiency. PAL recorded the minimum efficiency score of 0.612 . The median is 71.8 while the standard deviation is 7.8 . The pension industry is Nigeria seems to be less competitive to engender robust competitions among the players, which may eventually translate to higher efficiency. 


\section{Conclusions and Recommendations}

The result of the analyses of the technical efficiency of the pension fund administrators showed that technical inefficiency exists in the management of pension fund in Nigeria and the level of inefficiencies differs from one pension fund administrator to another, and none of the sampled PFAs is perfectly technically efficient. Besides, increase in profitability, number of contributors, engaging in open fund investment activities and merger and acquisition reduce operating costs. An industry-wide merger and acquisition may be initiated by the regulator to bring about synergy and economic of scales that will reduce cost of operations and generate higher returns to members of the contributory pension scheme. Besides, pension managers in Nigeria should regularly publish their annual and efficiency reports to woo potential contributors to gain operating costs curtailment with the attendant increase in profit. PENCOM should also engender competition in the pension industry by opening the transfer windows for existing contributors to move from one pension to another as these windows have not been opened since 2004 even though the Pension Reform Act of 2004 makes provision for it.

Finally, for pension fund to be managed efficiently, regulatory infrastructure should be robust to mitigate unnecessary input costs on labour, equipment and premises with negative impact on pension contributions and investment returns. This becomes necessary because input costs of labour, equipment and premises are presently being incurred by the pension fund administrators in Nigeria at their discretion without recourse to regulatory authorityas there is no regulation on the curtailment of these costs which have negative consequences on post-employment benefits of the contributors.

\section{Conflicts of Interest}

There is no conflict of interest.

\section{References}

Abade, R. (2004). Pension Reform Act 2004: What Is in It for You? http://www.newageonline.com/

Ahmat, K., Aykut, K., \& Huseyin, D. (2013). Improvement of Private Pension in Turkey and Measurement of Its Efficiency with Data Envelopment Analysis. Journal of Economics and Finance, 5, 163-173. https://doi.org/10.5539/ijef.v5n11p163

Aigner, D. J., Lovell, C. A. K., \& Schmidt, P. (1977). Formulation and Estimation of Stochastic Frontier Production Function Models. Journal of Econometrics, 6, 21-37. https://doi.org/10.1016/0304-4076(77)90052-5

Barrientos, A., \& Boussofiane, A. (2005). How Efficient Are Pension Fund Managers in Chile? Revista de Economia Contempornea, 9, 289-311. https://doi.org/10.1590/S1415-98482005000200003

Barros, C. P., \& Garcia, M. T. M. (2006). Performance Evaluation of Pension Funds Management Companies' Data Envelopment Analysis. Risk Management and Insurance Review, 9, 165-188. https://doi.org/10.1111/j.1540-6296.2006.00092.x

Barros, C. P., \& Garcia, M. T. M. (2007). Analysing the Performance of the Pension Fund 
Industry with Stochastic Frontier Model: A Case Study of Portugal. The Geneva Papers on Risk and Insurance-Issues and Practice, 32, 190-210.

https://doi.org/10.1057/palgrave.gpp.2510126

Barros, C. P., Ferro, G., \& Romero, C. (2008). Technical Efficiency and Heterogeneity of Argentina Pension Funds. Department of Economics Working Paper 29/2008/DE/UECE, Lisbon: Technical University of Lisbon.

Battese, G. E., \& Coelli, T. J. (1988). Prediction of Firm-Level Technical Efficiencies with a Generalised Frontier Production Function and Panel Data. Journal of Econometrics, 38, 387-399. https://doi.org/10.1016/0304-4076(88)90053-X

Battese, G. E., \& Corra, G. S. (1977). Estimation of a Production Frontier Model: With Application to the Pastoral Zone of Eastern Australia. Australian Journal of Agricultural Economics, 21, 169-179. https://doi.org/10.1111/j.1467-8489.1977.tb00204.x

Braberman, D. G., Chisari, L., Quesada, L., \& Rossi, A. M. (1999). Performance of Argentina Pension Fund Management Institutions. Revista de Analisis Economico, 14, 121-142.

Charnes, A., Cooper, W. W., \& Rhodes, E. (1978). Measuring the Efficiency of Decision-Making Units. European Journal of Operational Research, 2, 429-444. https://doi.org/10.1016/0377-2217(78)90138-8

Coelli, T. J. (1996). A Guide to Frontier Version 4.1: A Computer Program for Stochastic Frontier Production and Cost Function Estimation. Centre for Efficiency and Productivity Analysis Working Paper No. 7/96, Armidale: University of New England.

Coelli, T. J., Rao, P., \& Battese, G. E. (1998). An Introduction to Efficiency and Productivity Analysis (pp. 263-288). Boston, MA: Kluwer Academic Press. https://doi.org/10.1007/978-1-4615-5493-6

Dalkılıç, N., \& Ada, A. A. (2014). Efficiencies of Life and Pension Insurance Industry in Turkey: An Application of Data Envelopment Analysis. Journal of Applied Finance and Banking, 4, 181-191.

Farrell, M. J. (1957). The Measurement of Productive Efficiency. Journal of the Royal Statistical Society, 120, 253-290. https://doi.org/10.2307/2343100

Ferro, G., Romero, C. A., \& Covelli, M. P. (2011). Regulation and Performance: A Production Frontier Estimate for the Latin America Water and Sanitation Sector. Utilities Policies, 19, 211-217. https://doi.org/10.1016/j.jup.2011.08.003

Garcia, M. T. M. (2004). An Analysis of Pension Funds in Portugal. Pensions-An International Journal, 9, 227-245. https://doi.org/10.1057/palgrave.pm.5940266

Garcia, M. T. M. (2010). Efficiency Evaluation of the Portuguese Pension Fund Management Companies. Journal of International Financial Markets, Institutions and Money, 20, 259-266. https://doi.org/10.1016/j.intfin.2010.03.003

Gouhua, F., \& Apostolos, S. (2009). Efficiency and Productivity of the US Banking Industry, 1998-2005: Evidence from Fourier Cost Function Satisfying Global Regulatory Conditions. Journal of Applied Econometrics, 24, 105-138. https://doi.org/10.1002/jae.1021

Greene, W. H., \& Segal, D. (2004). Profitability and Efficiency in the U.S. Life Insurance Policy. Journal of Productivity Analysis, 21, 229-247. https://doi.org/10.1023/B:PROD.0000022092.70204.fa

Greene, W.H. (2005). Econometric Analysis (5th ed.) Upper Saddle River, New Jersey: Prentice Hall.

Karim, M. Z. A. (2001). Comparative Bank Efficiency across Selected ASEAN Countries. ASEAN Economic Bulletin, 18, 289-304. https://doi.org/10.1355/AE18-3D 
Keshari, P. K., \& Paul, M. T. (1994). Relative Efficiency of Foreign and Domestic Banks. Economic and Political Weekly, 29, 31-36.

Lozano-Vivas, A., Kumbhakar, S. C., Fethi, M. D., \& Shaban, M. (2011). Consolidation in European Banking Industry: How Effective Is It? Journal of Productivity Analysis, 36, 247-261. https://doi.org/10.1007/s11123-011-0212-8

Meeusen, W., \& Van de Broeck, J. (1977). Efficiency Estimation from Cobb-Douglas Production Functions with Composed Error. International Economic Review, 18, 435-444. https://doi.org/10.2307/2525757

Odia, J. O., \& Okoye, A. E. (2012). Pension Reform in Nigeria: A Comparison between the Old and New Scheme. Afro Asian Journal of Social Sciences, 3, 1-17.

Orifowomo, O. A. (2006). A Critical Appraisal of Pension System Reforms in Nigeria. Gonzaga Journal of International Law, 10, 164.

PENCOM (2018) National Pension Commission Annual Report 2017.

PENCOM Annual Reports (2011-2015) National Pension Commission. http://www.pensionnig.org/

Pension Reform Act (PRA) (2014) PENCOM Website. http://www.pensionnig.org/

Subrahmanyam, G., \& Swami, S. B. (1992). Bilateral Productivity and Performance Comparisons of Public Sector Banks in India, NIBM, Pune (Monograph). 